\title{
A Model System for Studying the Effects of Colloidal Calcium Phosphate Concentration on the Rheological Properties of Cheddar Cheese
}

\author{
J. A. O'Mahony, ${ }^{*} \dagger$ P. L. H. McSweeney, ${ }^{*}$ and J. A. Lucey ${ }^{1}$ \\ *Department of Food and Nutritional Sciences, University College, Cork, Ireland \\ †Department of Food Science, University of Wisconsin, Madison 53706-1565
}

\begin{abstract}
A novel model system was developed for studying the effects of colloidal Ca phosphate (CCP) concentration on the rheological properties of Cheddar cheese, independent of proteolysis and any gross compositional variation. Cheddar cheese slices (disks; diameter $=50 \mathrm{~mm}$, thickness $=2 \mathrm{~mm}$ ) were incubated in synthetic Cheddar cheese aqueous phase solutions for $6 \mathrm{~h}$ at $22^{\circ} \mathrm{C}$. Control (unincubated) Cheddar cheese had a total $\mathrm{Ca}$ and CCP concentration of $2.80 \mathrm{~g} / 100 \mathrm{~g}$ of protein and $1.84 \mathrm{~g}$ of $\mathrm{Ca} / 100 \mathrm{~g}$ of protein, respectively. Increasing the concentration of $\mathrm{Ca}$ in the synthetic Cheddar cheese aqueous phase solution incrementally in the range from 1.39 to $8.34 \mathrm{~g} / \mathrm{L}$ significantly increased the total $\mathrm{Ca}$ and CCP concentration of the cheese samples from 2.21 to 4.59 $\mathrm{g} / 100 \mathrm{~g}$ of protein and from 1.36 to $2.36 \mathrm{~g}$ of $\mathrm{Ca} / 100 \mathrm{~g}$ of protein, respectively. Values of storage modulus (index of stiffness) at $70^{\circ} \mathrm{C}$ increased significantly with increasing concentrations of CCP, but the opposite trend was apparent at $20^{\circ} \mathrm{C}$. The maximum in loss tangent (index of meltability/flowability) decreased significantly with increasing concentration of CCP, and there was no significant effect on the temperature at which the maximum in loss tangent occurred (68 to $70^{\circ} \mathrm{C}$ ). Fourier transform mechanical spectroscopy showed the frequency dependence of all of the cheese samples increased with increasing temperature; however, solubilization of CCP increased the frequency dependence of the cheese matrix only in the high temperature region (i.e., $>35^{\circ} \mathrm{C}$ ). These results support earlier studies that hypothesized that the concentration of CCP strongly modulates the rheological properties of cheese.
\end{abstract}

Key words: Cheddar cheese, rheology, colloidal calcium phosphate

\section{INTRODUCTION}

Texture and functionality are two of the primary quality attributes of cheese, and their importance, rela-

Received August 5, 2005.

Accepted September 26, 2005.

${ }^{1}$ Corresponding author: jalucey@facstaff.wisc.edu tive to other attributes (such as flavor), is increasing as the market for cheese as a functional food ingredient continues to grow. However, the development of cheese texture and functionality is not exclusively associated with any single biochemical or physicochemical process during ripening, and as yet, the exact mechanisms responsible for texture development in cheese have not been fully elucidated. Proteolysis has long been considered one of the principal agents responsible for texture development in Cheddar cheese during ripening (Creamer and Olson, 1982; Lawrence et al., 1983, 1987; Guinee, 2003).

Approximately 6\% of the dry weight of casein micelles is composed of various minerals (Fox and McSweeney, 1998), of which Ca phosphate is the largest constituent. Colloidal Ca phosphate (CCP) is one of the primary structural elements of the casein micelle (Horne, 1998). Recently, it has been proposed that the solubilization of CCP also plays an important role in the development of the texture of mature Cheddar cheese, especially during the early stages of ripening (Lucey et al., 2003, 2005; O’Mahony et al., 2005).

Lucey and Fox (1993) first reported that as much as 80 to $90 \%$ of the total CCP content of milk is retained in Cheddar cheese curd immediately after manufacture. Those researchers also suggested that the proportions of $\mathrm{Ca}$ and phosphate in the insoluble form, as opposed to the total $\mathrm{Ca}$ and phosphate concentrations of cheese, are important in modulating cheese structure, texture, and functionality. Such an approach provides more information about manufacturing conditions (i.e., rate of acid production and $\mathrm{pH}$ at whey drainage). It is now possible to quantify accurately the proportion of total $\mathrm{Ca}$ in the insoluble form in cheese during ripening using an acid-base titration method (Lucey and Fox, 1993; Hassan et al., 2004). Using this approach, Lucey et al. (2005) reported that various rheological parameters [e.g., storage modulus $\left(\mathbf{G}^{\prime}\right)$ and maximum loss tangent $\left(\mathbf{L} \mathbf{T}_{\text {max }}\right)$ ] of Cheddar cheese were more highly correlated with the level of insoluble Ca than with the extent of primary proteolysis (as monitored by levels of $\mathrm{pH}$ 4.6soluble nitrogen) during ripening. O'Mahony et al. (2005) reported that the hardness of Cheddar cheese during the early stages of ripening ( 1 to $21 \mathrm{~d}$ ) was more 
highly correlated with the concentration of insoluble $\mathrm{Ca}$ $(\mathrm{r}=0.92 ; P \leq 0.001)$ than were levels of intact $\alpha_{\mathrm{s} 1}$-casein ( $\mathrm{r}=0.63 ; P>0.05)$ or levels of $\mathrm{pH} 4.6$-soluble nitrogen $(\mathrm{r}=0.76 ; P \leq 0.05)$ in cheese in which residual coagulant was inhibited. The conversion of $\mathrm{Ca}$ from insoluble to soluble forms in Cheddar cheese during ripening occurs most rapidly during the first $42 \mathrm{~d}$ of ripening (Hassan et al., 2004; Lucey et al., 2005; O'Mahony et al., 2005) and now appears to be largely responsible for the changes in rheological properties during this stage of ripening (Lucey et al., 2005; O'Mahony et al., 2005).

In recent years, several strategies have been used to study the importance of total Ca concentration, distribution of $\mathrm{Ca}$ between insoluble and soluble forms, or both in determining cheese structure, texture, and functionality. Studies have been confined largely to Mozzarella, and to a lesser extent, Cheddar cheese. Examples of such approaches include preacidification of cheesemilk (Creamer et al., 1985; Metzger et al., 2000; Guinee et al., 2002; Joshi et al., 2002, 2003), altering pH at whey drainage (Lee and Lucey, 2005), postmanufacture alteration of cheese pH (Kindstedt et al., 2001), postmanufacture alteration of $\mathrm{Ca}$ concentration of cheese (Pastorino et al., 2003), and manufacture of directly acidified cheese products (Guinee et al., 2002; Joshi et al., 2003; Sheehan and Guinee, 2004). However, several of these approaches have the inherent disadvantage of causing differences in composition between cheeses (including, but not confined to, changes in moisture, protein, $\mathrm{pH}$, fat in $\mathrm{DM}$, titratable acidity, lactose, and levels of residual chymosin activity). It has also proven extremely difficult to study the effects of CCP solubilization on rheological properties of Cheddar cheese without extent of proteolysis also being a variable. To date, the only study of this kind, O'Mahony et al. (2005), showed that the early ( $\mathrm{d} 1$ to 21 ) softening of texture was strongly influenced by CCP solubilization in Cheddar cheese in which chymosin-mediated proteolysis was inhibited using pepstatin. However, plasmin-mediated proteolysis and secondary proteolytic events (proteinase and peptidase activity of lactic acid bacteria) were not inhibited. Furthermore, the effects of CCP solubilization on the fundamental rheological properties of Cheddar cheese across a wide range of temperatures $\left(10\right.$ to $90^{\circ} \mathrm{C}$ ) warrant detailed study.

The objective of this study was to develop a model system to alter rapidly the CCP concentration of Cheddar cheese, which would allow determination of the effects of varying CCP concentration on rheological properties of Cheddar cheese for the same cheese sample (i.e., identical composition and physicochemical or biochemical history).

\section{MATERIALS AND METHODS}

\section{Synthetic Cheddar Cheese Aqueous Phase Solutions}

Synthetic Cheddar cheese aqueous phase (SCCAP) solutions were prepared based on the method developed by Broome and Limsowtin (2002) with some modifications. Those researchers formulated the original SCCAP solution based on data for concentrations of various elements (e.g., sodium, calcium, and phosphorus), organic acids, phosphate, and sulfate in the serum phase (juice) extracted from Cheddar cheese ( 1 mo old) by hydraulic pressure. For extraction of cheese juice, grated cheese ( 1 part) was mixed thoroughly with sand (2 parts) and packed into lined 6-cm diameter hoops and pressed using a hydraulic press to a maximum pressure of $1,076 \mathrm{~N} / \mathrm{cm}^{2}$ over $4.5 \mathrm{~h}$. The cheese juice (aqueous phase) was separated from the fat phase by centrifugation at $11,000 \times g$ for $5 \mathrm{~min}$. The cheese juice was collected and filtered through disposable $0.45-\mu \mathrm{m}$ cellulose acetate filters. Disodium hydrogen phosphate $(6.412 \mathrm{~g})$ was dissolved in $700 \mathrm{~mL}$ of deionized water (Milli-Q Reagent Water System, Millipore Corporation, Bedford, MA). Citric acid-monohydrate $(2.300 \mathrm{~g})$, sodium chloride (31.620 g), magnesium sulfate heptahydrate $(0.564 \mathrm{~g})$, magnesium chloride hexahydrate (3.296 $\mathrm{g})$, potassium chloride $(3.624 \mathrm{~g})$, and sodium acetate trihydrate $(0.600 \mathrm{~g})$ were then added in that order. Once the salts were dissolved completely ( $15 \mathrm{~min})$, sodium lactate ( $60.056 \mathrm{~g}$ of a $60 \% \mathrm{wt} / \mathrm{wt}$ syrup) was added. After stirring for $\sim 15 \mathrm{~min}$, the $\mathrm{pH}(\sim 6.12)$ was adjusted to $\mathrm{pH}$ 5.73 with lactic acid $(1.0 \mathrm{~N})$. With continued stirring, $10 \mathrm{~mL}$ of a solution of manganese chloride tetrahydrate $(0.025 \mathrm{~g} / 100 \mathrm{~mL}$ ) was added. An aliquot (15 to $90 \mathrm{~mL}$, which varied depending on the desired calcium content of the SCCAP solution) of a solution of calcium chloride dihydrate $(34.006 \mathrm{~g} / 100 \mathrm{~mL})$ was also added, followed by $10 \mathrm{~mL}$ of a solution of zinc chloride $(0.625 \mathrm{~g} / 100$ $\mathrm{mL}$ ). The $\mathrm{pH}$ (ranging from 5.35 to 5.65 , depending on quantity of calcium chloride dihydrate solution added) was adjusted to $\mathrm{pH} 5.35$ with hydrochloric acid $(0.5 \mathrm{~N})$, and the solution was made up to volume $(1 \mathrm{~L})$ with deionized water. Hydrochloric acid was used instead of lactic acid for $\mathrm{pH}$ adjustment at this point to ensure identical concentration of lactic acid in each of the SCCAP solutions. The $\mathrm{pH}$ was then adjusted to 5.1 with lactic acid $(1.0 \mathrm{~N})$. All chemical reagents used were of analytical grade (Fisher Scientific, Fair Lawn, NJ). In total, 5 separate solutions were prepared, differing only in the volume of calcium chloride dihydrate solution, i.e., $15,30,60,75$, or $90 \mathrm{~mL}$; total calcium levels were $1.39,2.78,5.56,6.95$, and $8.34 \mathrm{~g} / \mathrm{L}$, respectively. All solutions were prepared freshly on the day of use. 


\section{Incubation of Cheese in SCCAP Solutions}

Commercial blocks (20 kg) of 4-mo-old Cheddar cheese were obtained from Alto Dairy Cooperative (Waupun, WI). Cheese samples (disks; diameter $=50$ $\mathrm{mm}$, thickness $=2 \mathrm{~mm}$ ) were wrapped in a single layer of cheesecloth and placed in the base of a plastic Petri dish $(85 \times 15 \mathrm{~mm}) ; 50 \mathrm{~mL}$ of SCCAP solution was added. Cheesecloth was used to prevent adhesion of cheese samples to the interior surface of the Petri dish and to ensure contact between all surfaces of the cheese sample and the SCCAP solution. Petri dishes were covered with plastic lids to prevent evaporation during incubation. Eighteen cheese samples were incubated at $22^{\circ} \mathrm{C}$ for $6 \mathrm{~h}$ in each of the 5 SCCAP solutions. The contents of the Petri dishes (i.e., cheese sample and SCCAP solution) were continually agitated during incubation using a laboratory platform shaker (Lab-Line Instruments Inc., Melrose Park, IL) rotating at $\sim 30 \mathrm{rpm}$. Following incubation, the cheese samples were removed from the SCCAP solutions, and any surface moisture was removed using a tissue. The samples were allowed to dry in air for a total of $30 \mathrm{~min}$ with inversion after 15 min to give a postincubation moisture content of $\sim 44 \%$. Samples were then placed in sealed plastic bags and allowed to equilibrate at $5^{\circ} \mathrm{C}$ for $18 \mathrm{~h}$ before analysis. After incubation, the SCCAP solutions were pooled from the 18 Petri dishes for analysis of total calcium and $\mathrm{pH}$.

\section{Analysis of Cheese Composition}

The protein content of the cheeses was determined by the macro-Kjeldahl method (IDF, 1964), and moisture was determined by oven drying (IDF, 1982). $\mathrm{pH}$ of a slurry, obtained after homogenizing $4 \mathrm{~g}$ of cheese with $8 \mathrm{~g}$ of distilled water for $2 \mathrm{~min}$ at room temperature using a mortar and pestle, was determined using a glass $\mathrm{pH}$ electrode ( $\mathrm{pH}$ meter 420A, Orion Research Inc., Beverly, MA). The total Ca content of the cheeses was determined using atomic absorption spectroscopy (IDF, 2003). All cheese samples were analyzed for protein, moisture, $\mathrm{pH}$, and total calcium content before and after incubation. The insoluble calcium content of the unincubated (control) cheese was calculated from data for total calcium content and the concentration of calcium in cheese juice (i.e., soluble calcium). Cheese juice was extracted using high hydraulic pressure as described by Hassan et al. (2004), and the concentration of calcium was determined using atomic absorption spectroscopy. All analyses were conducted in triplicate.

\section{Composition of SCCAP Solution}

The composition of the SCCAP solutions, before incubation, was determined from the formulation data. The total calcium content of the SCCAP solutions, after incubation, was determined by atomic absorption spectroscopy (IDF, 2003). The $\mathrm{pH}$ of the SCCAP solutions after incubation was determined by direct immersion of a glass $\mathrm{pH}$ electrode ( $\mathrm{pH}$ meter 420A, Orion Research Inc.) into the solution. All analyses were conducted in triplicate.

\section{Determination of CCP Content of Cheese}

The CCP content of the cheese samples was determined by performing acid-base titrations on aqueous homogenates of cheese essentially as described by Hassan et al. (2004). Cheese samples were prepared for titration by homogenizing grated cheese $(8 \mathrm{~g})$ with 40 $\mathrm{mL}$ of deionized water $\left(55^{\circ} \mathrm{C}\right)$ for $3 \mathrm{~min}$ in an UltraTurrax homogenizer (T25 Basic with S25N-18G dispersing element, Ikaworks Inc., Wilmington, NC). The homogenate was allowed to cool to $25^{\circ} \mathrm{C}$ before titration.

An automated $\mathrm{pH}$ titration system (Mettler Toledo DL 50 Titrator, Schwerzenbach, Switzerland) was used for acid-base titration of cheese homogenates. The titration system was interfaced with a computer equipped with DLWin and DLBase software (Mettler Toledo DL 50 Titrator) for system control and data acquisition, respectively. The glass $\mathrm{pH}$ electrode (Mettler Toledo DG115 SE, Greifensee, Switzerland) was calibrated daily using buffer solutions at $\mathrm{pH} 4.0,7.0$, and 10.0 (Fisher Scientific, Fair Lawn, NJ). The slope of the calibration was maintained in the range from 56.5 to 58.5 $\mathrm{mV} / \mathrm{pH}$ (theoretical slope $=58.0 \mathrm{mV} / \mathrm{pH}$ ). Cheese homogenates were titrated from the initial $\mathrm{pH}$ of $\sim 5.2$ to $\mathrm{pH} 3.0$ with $0.5 \mathrm{~N} \mathrm{HCl}$ and back-titrated to $\mathrm{pH} 9.0$ with $0.5 \mathrm{~N} \mathrm{NaOH}$. Titrants were added in $0.1 \mathrm{~mL}$ increments at 30 -s intervals to allow for equilibration of titrant and homogenate.

The change in $\mathrm{pH}(\mathrm{dpH})$, generated by the incremental addition of acid or base, and the volume of titrant used in the titration were recorded by the titrator software and exported to a Microsoft Excel spreadsheet from the Microsoft Office 2000 Premium package (Microsoft Corporation, Redmond, WA). Buffering indices $(\mathrm{dB} / \mathrm{dpH})$ were calculated from these data according to Van Slyke (1922) as follows:

$$
\frac{\mathrm{dB}}{\mathrm{dpH}}=
$$

$\mathrm{mL}$ of acid or base added $\times$ normality of acid or base volume of sample $\times \mathrm{pH}$ change produced

Buffering curves were prepared by plotting buffering index as a function of $\mathrm{pH}$. The change in total volume of sample caused by the addition of acid or alkali during the titration was taken into account in the calculation 
of buffering indices. Microsoft Excel was used to calculate the area under the buffering curves. The curves were integrated between the $\mathrm{pH}$ limits of 4.1 and 5.2, which were based on the values reported by Hassan et al. (2004). The difference in area between the forward and back buffering curves was then calculated. The magnitude of this area is directly related to the CCP content of milk (Lucey et al., 1993) and cheese (Lucey and Fox, 1993; Hassan et al., 2004). The insoluble calcium (i.e., CCP) content of the cheese slices was calculated as described by Hassan et al. (2004). To compensate for differences in moisture content of the cheeses on incubation in SCCAP solutions, the CCP content of the cheeses was expressed as grams of calcium $/ 100$ grams of protein. All analyses were conducted in triplicate.

\section{Determination of Rheological Properties}

Small Deformation Rheological Properties. The small deformation viscoelastic properties of the cheeses were determined by Fourier transform mechanical spectroscopy (FTMS) using a Paar Physica universal dynamic spectrometer (UDS 200, Physica Messtechnik, Stuttgart, Germany) as described by Udayarajan et al. (2005). The frequencies selected for the complex waveform were $0.04,0.08,0.4,0.8,4$, and $8 \mathrm{~Hz}$, and the cumulative strain was set at $0.27 \%$ (i.e., within the linear viscoelastic range; Udayarajan et al., 2005). The rheometer was equipped with a $50 \mathrm{~mm}$ diameter serrated parallel plate. Samples (diameter $=50 \mathrm{~mm}$; thickness $=2 \mathrm{~mm}$ ) were mounted and glued to the bottom heating plate (peltier) of the rheometer to prevent slippage (Nolan et al., 1989; Tunick et al., 1990; Lucey et al., 2005). Samples were loaded based on normal force (NF) readings. The top (serrated) plate was lowered onto the sample to give an NF reading ranging from 1.4 to $1.6 \mathrm{~N}$. The sample was then allowed to relax from the stress applied during loading until a lower and relatively constant $\mathrm{NF}$ reading of $\sim 0.7 \mathrm{~N}$ was attained. This procedure ensured sufficient contact between the cheese sample and the serrated plate of the rheometer for transmission of applied stress during analysis without excessive compression (deformation) of the sample. The exposed edge of the sample was covered with a thin layer of vegetable oil to prevent moisture loss during heating. The rheological parameters, $\mathrm{G}^{\prime}$, loss modulus $\left(\mathbf{G}^{\prime \prime}\right)$, and loss tangent (LT) were recorded at 1-min intervals and reported as a function of temperature for each sample while heating from 10 to $90^{\circ} \mathrm{C}$ at a constant rate of $1^{\circ} \mathrm{C} / \mathrm{min}$. Each sample was analyzed at least 4 times.

Large Deformation Rheological Properties. The large deformation rheological properties of cheese sam- ples incubated in SCCAP solutions containing 1.39 or $6.95 \mathrm{~g}$ of calcium/ $\mathrm{L}$ for $6 \mathrm{~h}$ at $22^{\circ} \mathrm{C}$, were determined using a TA-XT2i texture analyzer (Stable Micro Systems, Godalming, Surrey, UK). Six cheese disks [diameter $=50 \mathrm{~mm}$, thickness $=2 \mathrm{~mm}$ (before incubation) $]$ were stacked on top of each other after incubation, placed in airtight plastic bags, and equilibrated at $4^{\circ} \mathrm{C}$ for $18 \mathrm{~h}$. Six cylindrical samples (diameter $=13 \mathrm{~mm}$, height $\sim 14$ $\mathrm{mm}$ ) were cut from the stack of cheese disks using a stainless steel borer and equilibrated at $4^{\circ} \mathrm{C}$ for a further $30 \mathrm{~min}$ prior to compression. Samples were removed from the incubator and immediately compressed to $25 \%$ of original height at a rate of $1 \mathrm{~mm} / \mathrm{s}$. The force at 5,20 , and $75 \%$ compression, stain at fracture, force at fracture, adhesive force, and adhesiveness were recorded. Adhesive force and adhesiveness were defined as the maximum force and the negative force area representing the work necessary to retract the probe from the compressed sample, respectively (Bourne, 1978).

\section{Statistical Data Analysis}

One-way ANOVA of data for the composition and rheological properties of cheese samples incubated in SCCAP solutions with varying concentrations of calcium was conducted using SPSS Version 11.0 for Windows XP (SPSS Inc., Chicago, IL). Pearson's correlation coefficients were estimated between CCP concentration of cheeses after incubation and several of the rheological parameters (i.e., $\mathrm{G}^{\prime}$ value at 20 and $70^{\circ} \mathrm{C}, \mathrm{LT}$ value at 20 and $70^{\circ} \mathrm{C}, \mathrm{LT}_{\max }$, temperature at $\mathrm{LT}_{\max }$, and exponent values from $\log \mathrm{G}^{\prime}$ vs. log frequency plots at 20 and at $70^{\circ} \mathrm{C}$ using SAS Institute (1999).

\section{RESULTS AND DISCUSSION}

\section{Buffering Curves from Acid-Base Titration}

The buffering curves obtained from acid-base titration of aqueous homogenates of control cheese and cheese samples incubated in SCCAP solutions with calcium concentrations varying from 1.39 to $8.34 \mathrm{~g} / \mathrm{L}$ are shown in Figure 1. All cheeses had a buffering peak at $\mathrm{pH} \sim 4.8$ on titration from the initial $\mathrm{pH}$ (5.2 to 5.3) to $\mathrm{pH} 3.0$ with acid. This buffering peak was due to solubilization of CCP, which released phosphate ions that can combine with $\mathrm{H}^{+}$in solution, resulting in buffering (Lucey and Fox, 1993). The buffering peak at $\mathrm{pH}$ 5.5 to 6.8 on titration from $\mathrm{pH} 3.0$ to 9.0 with $\mathrm{NaOH}$ also increased with increasing concentration of calcium from 1.39 to $8.34 \mathrm{~g} / \mathrm{L}$ (Figure 2). This buffering peak was caused by precipitation of calcium phosphate with the release of $\mathrm{H}^{+}$(Lucey and Fox, 1993) and increased in magnitude with increasing amount of CCP that was solubilized during the forward titration with acid. The 

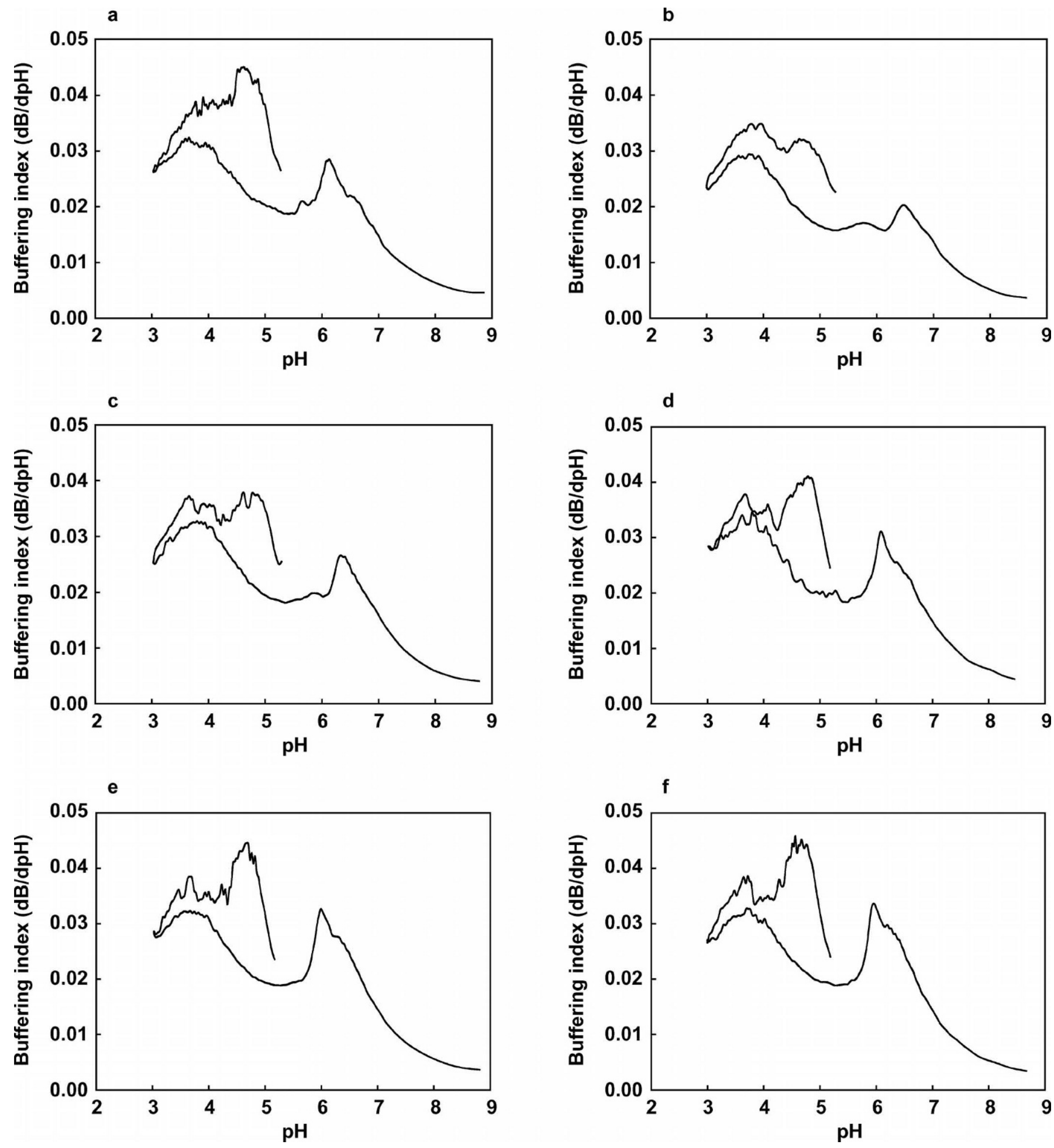

Figure 1. Acid-base buffering curves of control (unincubated) Cheddar cheese (a) and Cheddar cheese slices after incubation in synthetic Cheddar cheese aqueous phase solutions containing 1.39 (b), 2.78 (c), 5.56 (d), 6.95 (e), or 8.34 (f) g of calcium/L for $6 \mathrm{~h}$ at $22^{\circ} \mathrm{C}$; cheese samples were titrated from their initial $\mathrm{pH}$ to $\mathrm{pH} 3.0$ with $0.5 \mathrm{~N} \mathrm{HCl}$ and then back-titrated to $\mathrm{pH} 9.0$ with $0.5 \mathrm{~N} \mathrm{NaOH}$.

$\frac{\mathrm{dB}}{\mathrm{dpH}}=\frac{\mathrm{mL} \text { of acid or base added } \times \text { normality of acid or base }}{\text { volume of sample } \times \mathrm{pH} \text { change produced }}$. 


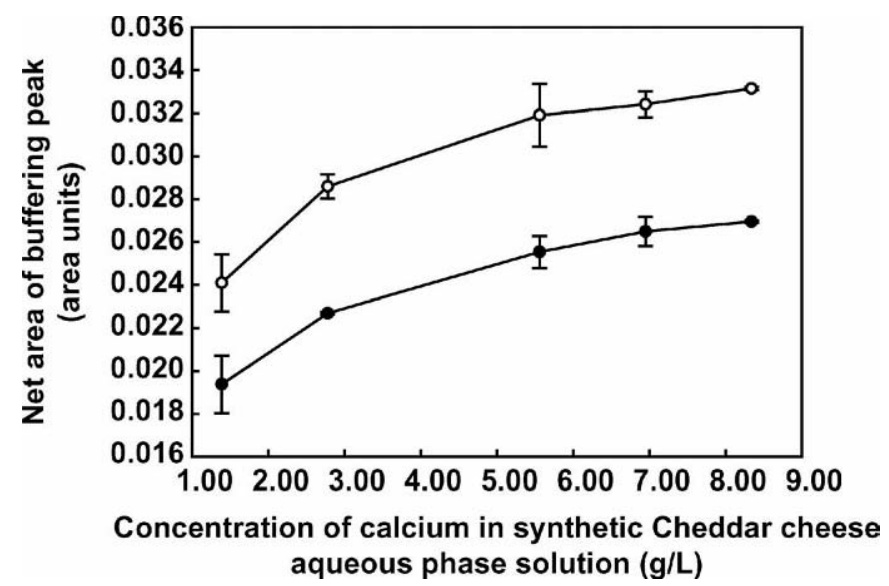

Figure 2. Net area of buffering peak between $\mathrm{pH}$ limits of 4.1 and 5.2 during acid titration $(\bullet)$ and area under buffering curve between $\mathrm{pH}$ limits of 5.5 and 6.8 during base titration $(\bigcirc)$ for Cheddar cheese slices after incubation in synthetic Cheddar cheese aqueous phase solutions for $6 \mathrm{~h}$ at $22^{\circ} \mathrm{C}$. Error bars indicate $\pm 1 \mathrm{SD}(\mathrm{n}=3)$.

magnitude of the net titration peak area between the $\mathrm{pH}$ limits 4.1 and 5.2 increased steadily with increasing calcium concentration in the SCCAP solutions in the range from 1.39 to $8.34 \mathrm{~g} / \mathrm{L}$ (Figures 1 and 2). It has been reported that the magnitude of the area of the net titration peak between the $\mathrm{pH}$ limits 4.1 and 5.2 decreased steadily with progressive solubilization of CCP during ripening of Cheddar cheese (Hassan et al., 2004). The CCP content of cheese samples incubated in SCCAP solutions containing 5.56, 6.95, and $8.34 \mathrm{~g}$ of calcium/L was greater than that of the control cheese (Table 1). The shapes of the corresponding acid-base titration curves (Figure 1, $d$ through $\mathrm{f}$ ) were identical to those of the control cheese (Figure 1a) and the increased buffering capacity of these cheese samples occurred within the $\mathrm{pH}$ limits 4.1 and 5.2. There was a parallel increase in the net titration peak area between the $\mathrm{pH}$ limits of 4.1 and 5.2 and the area under the buffering curve between the $\mathrm{pH}$ limits of 5.5 and 6.8 with increasing concentration of calcium in the SCCAP solutions
(Figure 2). These observations suggest that the type of insoluble (colloidal) Ca phosphate formed in the cheese samples incubated in SCCAP solutions containing 5.56, 6.95 , and $8.34 \mathrm{~g}$ of calcium/L was identical in nature to that of the control cheese.

\section{Cheese Composition}

The compositions of the control cheese (i.e., cheese before incubation in SCCAP solution) and the cheeses incubated in SCCAP solutions containing 1.39, 2.78, $5.56,6.95$, or $8.34 \mathrm{~g}$ of calcium/L are shown in Table 1 . The composition of the control cheese with $\mathrm{pH}$, moisture, and protein content of $5.25,36.5 \%$, and $24.8 \%$, was typical of good quality commercial Cheddar cheese (Gilles and Lawrence, 1973; Fox et al., 2000). The total calcium content of the cheese samples increased with increasing concentration of calcium in the SCCAP solutions; cheese samples incubated in SCCAP solutions containing 1.39 or $8.34 \mathrm{~g}$ of calcium/L had total calcium concentrations of 2.21 and $4.59 \mathrm{~g} / 100 \mathrm{~g}$ of protein, respectively (Table 1 ). Thus, varying the concentration of calcium in the incubation medium altered the total calcium concentration of the Cheddar cheese used in this study. The increase in CCP concentration paralleled this increase in total calcium content of the cheese samples with increasing concentration of calcium in the SCCAP solutions (Table 1). The CCP levels ranged from 1.36 to $2.36 \mathrm{~g}$ of calcium/100 $\mathrm{g}$ of protein for samples incubated in SCCAP solutions containing 1.39 and 8.34 $\mathrm{g}$ of calcium/L, respectively. Of note, it was possible either to increase or decrease the original CCP concentration of the control cheese by careful selection of the calcium concentration in the SCCAP solution. Cheese samples incubated in SCCAP solutions containing 6.95 or $8.34 \mathrm{~g}$ of calcium/L had CCP concentrations of 2.16 and $2.36 \mathrm{~g}$ of calcium $/ 100 \mathrm{~g}$ of protein, respectively, in comparison to $1.84 \mathrm{~g}$ of calcium/100 g of protein for the control cheese. Conversely, cheese samples incubated in SCCAP solutions with Ca concentration of 1.39 or $2.78 \mathrm{~g} / \mathrm{L}$ had significantly $(P<0.05)$ lower concentra-

Table 1. Composition of control (unincubated) Cheddar cheese and Cheddar cheese slices after incubation in synthetic Cheddar cheese aqueous phase solutions for $6 \mathrm{~h}$ at $22^{\circ} \mathrm{C}$

\begin{tabular}{lllllll}
\hline & & \multicolumn{5}{c}{ Concentration of calcium in buffer, g/L } \\
\cline { 3 - 6 } Parameter & Control & 1.39 & 2.78 & 5.56 & 6.95 \\
\hline pH & $5.25^{\mathrm{c}} \pm 0.03$ & $5.41^{\mathrm{a}} \pm 0.02$ & $5.28^{\mathrm{b}} \pm 0.01$ & $5.22^{\mathrm{bc}} \pm 0.01$ & $5.19^{\mathrm{d}} \pm 0.01$ & $5.12^{\mathrm{e}} \pm 0.01$ \\
Moisture, \% & $36.5^{\mathrm{a}} \pm 0.09$ & $45.9^{\mathrm{b}} \pm 0.09$ & $44.1^{\mathrm{c}} \pm 0.18$ & $44.3^{\mathrm{c}} \pm 0.20$ & $44.1^{\mathrm{c}} \pm 0.09$ & $43.7^{\mathrm{d}} \pm 0.11$ \\
Protein, \% & $24.8^{\mathrm{a}} \pm 0.24$ & $19.2^{\mathrm{b}} \pm 0.25$ & $19.5^{\mathrm{b}} \pm 0.29$ & $19.4^{\mathrm{b}} \pm 1.08$ & $19.7^{\mathrm{b}} \pm 0.24$ & $19.4^{\mathrm{b}} \pm 0.02$ \\
Total calcium, g/100 g of protein & $2.80^{\mathrm{c}} \pm 0.11$ & $2.21^{\mathrm{e}} \pm 0.03$ & $2.67^{\mathrm{c}} \pm 0.06$ & $3.60^{\mathrm{d}} \pm 0.03$ & $4.07^{\mathrm{b}} \pm 0.02$ & $4.59^{\mathrm{a}} \pm 0.13$ \\
CCP, g of calcium/100 g of protein & $1.84^{\mathrm{a}} \pm 0.02$ & $1.36^{\mathrm{b}} \pm 0.06$ & $1.56^{\mathrm{b}} \pm 0.15$ & $1.88^{\mathrm{a}} \pm 0.11$ & $2.16^{\mathrm{c}} \pm 0.02$ & $2.36^{\mathrm{c}} \pm 0.04$ \\
\hline
\end{tabular}

${ }^{\mathrm{a}-\mathrm{e}}$ Means in a row sharing the same superscript are not significantly different from each other (Tukey's HSD; $P \leq 0.05$ ).

${ }^{1} \mathrm{CCP}=$ Colloidal calcium phosphate content of cheese. 

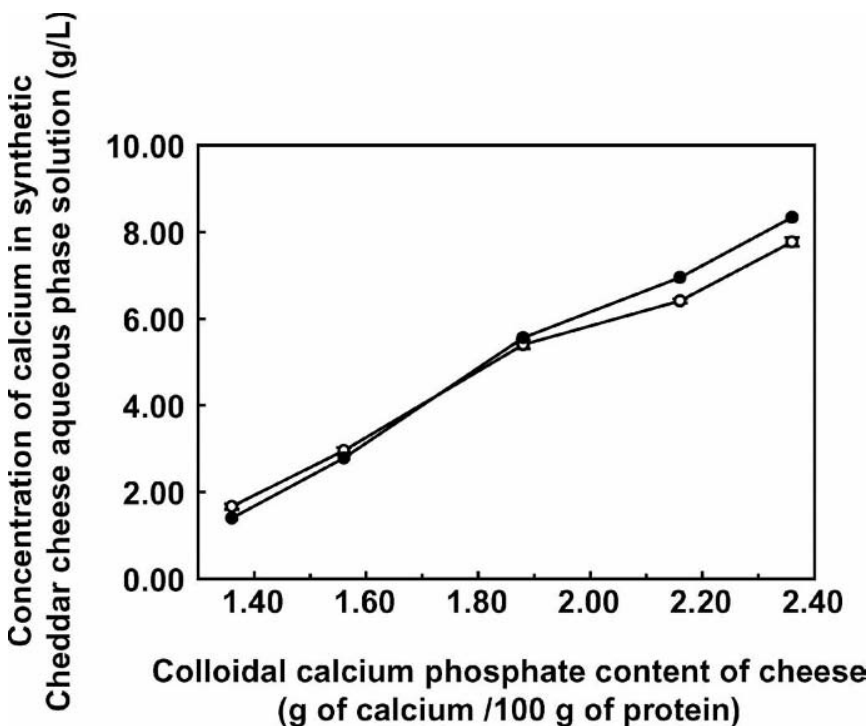

Figure 3. Concentration of calcium in synthetic Cheddar cheese aqueous phase solutions before $(\bullet)$ and after $(O)$ incubation of Cheddar cheese slices in synthetic Cheddar cheese aqueous phase solutions for $6 \mathrm{~h}$ at $22^{\circ} \mathrm{C}$ as a function of the colloidal calcium phosphate content of the cheese slices. Error bars indicate $\pm 1 \mathrm{SD}(\mathrm{n}=3)$.

tions of CCP than that of the control cheese after incubation. The CCP levels in the cheese sample with the highest concentration of CCP $(2.36 \mathrm{~g}$ of calcium $/ 100 \mathrm{~g}$ of protein) was $\sim 1.7$-fold greater than that of the lowest ( $1.36 \mathrm{~g}$ of calcium $/ 100 \mathrm{~g}$ of protein), which facilitated the study of the effects of CCP concentration on rheological properties of Cheddar cheese over a greater concentration range than that which normally occurs during ripening in Cheddar cheese.

The concentration of $\mathrm{Ca}$ in the serum phase of the control cheese used in this study was $700 \mathrm{mg} / 100 \mathrm{~g}$; this equates to $65.7 \%$ of total calcium being in the insoluble form. This value is similar to the range of 55 to $65 \%$ previously reported for Cheddar cheese after 4 mo of ripening (Hassan et al., 2004; Lucey et al., 2005; O'Mahony et al., 2005). Solubilization of CCP during incubation only occurred in those cheese samples where the concentration of calcium in the SCCAP solution (1.39 and $2.78 \mathrm{~g} / \mathrm{L}$ ) was lower than that of the serum phase of the cheese (Table 1). The concentration of calcium in the SCCAP solutions also increased during incubation for these 2 treatments (Figure 3), suggesting that calcium was leached from the cheese matrix. When other factors (e.g., acid production by lactic acid bacteria) serve to promote solubilization of calcium, this phenomenon (i.e., a concentration gradient between the colloidal and soluble forms of calcium) presumably acts as the driving force responsible for the partial solubilization of CCP in Cheddar cheese during ripening, as observed by Hassan et al. (2004), Lucey et al. (2005), and O’Ma- hony et al. (2005). On formulating the SCCAP solutions, it was noted that it was not possible to exceed a calcium concentration of $9.00 \mathrm{~g} / \mathrm{L}$ as precipitation occurred rapidly. By extrapolation, these observations suggest that the limit of solubility for calcium phosphate in the serum phase of natural Cheddar cheese may be in the approximate range of 850 to $900 \mathrm{mg} / 100 \mathrm{~g}$. However, the actual limit of solubility is likely to be governed by a range of factors, including $\mathrm{pH}$, temperature, presence of other ions, ionic strength, etc.

In general, the moisture content of the cheese samples after incubation increased with decreasing concentration of calcium in the SCCAP solutions. There were no significant $(P>0.05)$ differences between the moisture content of cheese samples incubated in SCCAP solutions containing $2.78,5.56$, or $6.95 \mathrm{~g}$ of calcium/L. Cheese samples incubated in SCCAP solutions containing 1.39 or $8.34 \mathrm{~g}$ of calcium/L had the highest and lowest moisture contents, respectively. This inverse relationship between CCP concentration and moisture content of the cheese samples is due to increased swelling and hydration of the para-casein matrix of the cheese as CCP is solubilized. This phenomenon has been demonstrated in milk; Sood et al. (1979) reported that voluminosity and solvation of casein micelles in milk increased from 3.72 to $4.16 \mathrm{~mL} / \mathrm{g}$ and from 3.02 to $3.46 \mathrm{~g}$ of water/g of protein, respectively, on decreasing the micellar calcium concentration from 19.5 to 15.7 $\mathrm{mmol} / \mathrm{L}$. It has also been shown that the swelling and hydration of casein micelles in renneted milk (Monib, 1962) and swelling of the para-casein matrix of cheese during brining (Geurts et al., 1972) are greatly reduced by increasing the concentration of calcium in the extraction or brine solutions. Similarly, the level of expressible serum in Mozzarella cheese was reported to decrease approximately 4 -fold during the first $16 \mathrm{~d}$ of ripening, while the level of calcium in the serum phase increased from 300 to $430 \mathrm{mg} / 100 \mathrm{~g}$ (Guo and Kindstedt, 1995). During this stage of ripening, the levels of CP (constituted mainly by intact caseins) in the serum phase of Mozzarella cheese have been reported to increase $\sim 3$-fold (Guo and Kindstedt, 1995; Kindstedt, 2004). Although the uptake of sodium chloride by the casein matrix from the serum phase of the cheese and its solubilizing action on casein are partly responsible for the reduction in levels of expressible serum, conversion of calcium from insoluble to soluble form also favors increased casein solvation and greater water-holding capacity, resulting in decreased levels of expressible serum (Guo and Kindstedt, 1995; Kindstedt, 2004).

The $\mathrm{pH}$ of the cheese samples incubated in SCCAP solutions increased with decreasing concentration of calcium in the SCCAP solutions (Table 1; Figure 4). Solubilization of CCP releases phosphate ions, which 


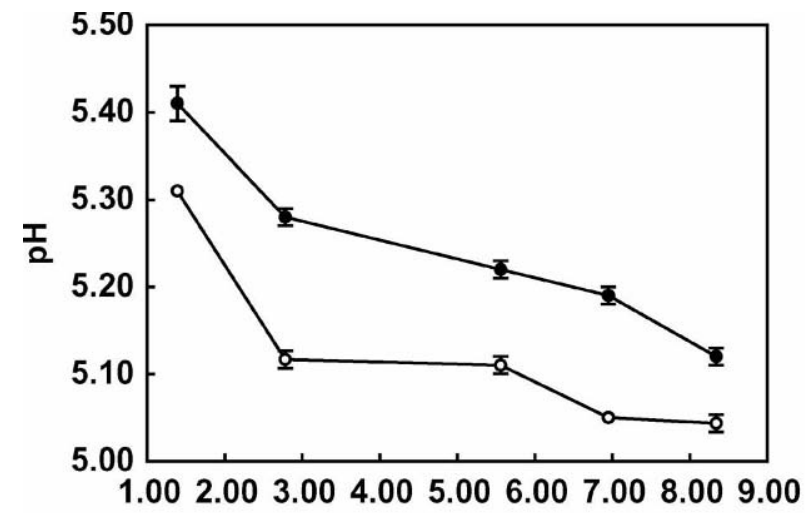

Concentration of calcium in synthetic Cheddar cheese aqueous phase solution (g/L)

Figure 4. $\mathrm{pH}$ of cheese $(\bullet)$ and synthetic Cheddar cheese aqueous phase solution $(O)$ after incubation of Cheddar cheese slices in synthetic Cheddar cheese aqueous phase solutions for $6 \mathrm{~h}$ at $22^{\circ} \mathrm{C}$. Error bars indicate $\pm 1 \mathrm{SD}(\mathrm{n}=3)$.

combine with hydrogen ions in solution, causing an increase in $\mathrm{pH}$ (Lucey et al., 1993). This was evident in cheese samples incubated in SCCAP solutions containing 1.39 and $2.78 \mathrm{~g}$ of calcium/L, each with significantly $(P \leq 0.05)$ higher $\mathrm{pH}$ (5.41 and 5.28, respectively) than the control cheese ( $\mathrm{pH} 5.25)$. The $\mathrm{pH}$ of cheese samples in which CCP was formed during incubation decreased from 5.25 (control cheese) to 5.22, 5.19, and 5.12 for cheese samples incubated in SCCAP solutions containing $5.56,6.95$, and $8.34 \mathrm{~g}$ of calcium/L, respectively. The formation of CCP during incubation would have involved uptake of phosphate and calcium ions from the serum phase of the cheese samples and the incubation medium. Such phosphate ions would most likely have been protonated; thus, uptake of phosphate for CCP formation released hydrogen ions, causing a decrease in $\mathrm{pH}$. Evidence for the formation of CCP in these 3 cheese samples during incubation may also be drawn from the decrease in $\mathrm{Ca}$ concentration of the SCCAP solutions containing 5.56, 6.95, and $8.34 \mathrm{~g}$ of calcium/L during incubation (Figure 3).

\section{Rheological Properties}

Small Deformation Rheological Properties. The changes in $\mathrm{G}^{\prime}, \mathrm{G}^{\prime \prime}$, and LT measured at a frequency of $0.4 \mathrm{~Hz}$ during heating from 10 to $90^{\circ} \mathrm{C}$ are shown in Figure 5. As expected from previous studies, the values for both dynamic moduli decreased with increasing temperature (Guinee et al., 1999; Venugopal and $\mathrm{Mu}-$ thukumarappan, 2003; Lucey et al., 2005; Udayarajan et al., 2005). On heating, there were no clear differences between the $\mathrm{G}^{\prime}$ values of any of the 5 cheese samples
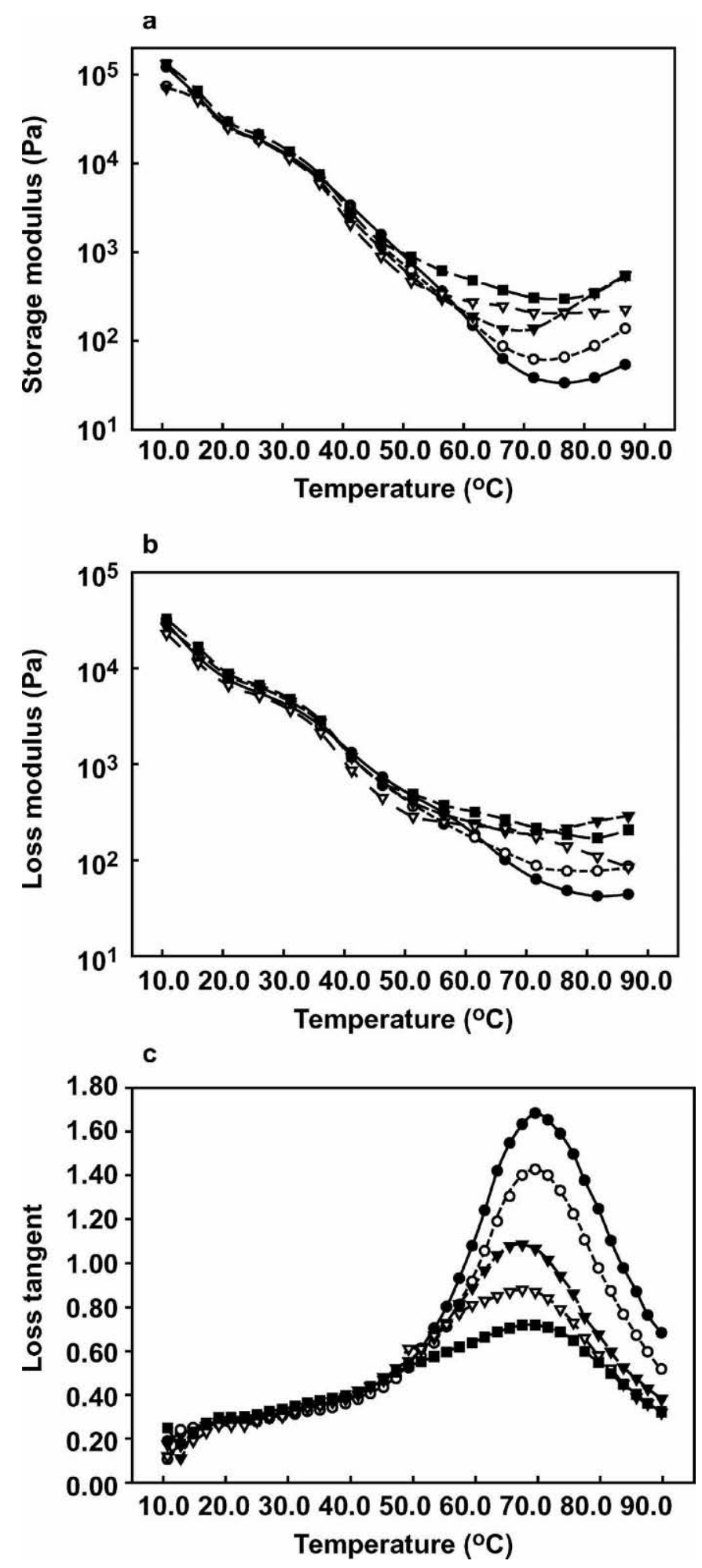

Figure 5. Storage modulus (a), loss modulus (b), and loss tangent (c) for Cheddar cheese slices incubated for $6 \mathrm{~h}$ at $22^{\circ} \mathrm{C}$ in synthetic Cheddar cheese aqueous phase solutions containing $1.39(\bullet), 2.78$ $(\bigcirc), 5.56(\nabla), 6.95(\nabla)$, or $8.34(\square) \mathrm{g}$ of calcium/L on heating from 10 to $90^{\circ} \mathrm{C}$ at a rate of $1^{\circ} \mathrm{C} / \mathrm{min}$ and a frequency of $0.4 \mathrm{~Hz}$. Values are means from 4 replicates. 
until a temperature of approximately $50^{\circ} \mathrm{C}$ was reached, and on further heating, a divergence was seen in the $G^{\prime}$ and $G^{\prime \prime}$ values with changing CCP concentration (Figure $5 \mathrm{a}, \mathrm{b}$ ). At $70^{\circ} \mathrm{C}$, the values for $\mathrm{G}^{\prime}$ increased significantly $(P \leq 0.05)$ with increasing concentration of CCP (Table 2). A graphical representation of the effects of CCP concentration on the rheological properties of the cheese samples at $70^{\circ} \mathrm{C}$ is shown in Figure 6. It is clear that at low concentrations of CCP (i.e., < $2.00 \mathrm{~g}$ of calcium $/ 100 \mathrm{~g}$ of protein), G" was greater than $\mathrm{G}^{\prime}$, indicating a dominance of liquid-like rheological properties. However, at higher concentrations of CCP, solid-like rheological properties dominated (i.e., $\mathrm{G}^{\prime}$ > $\left.\mathrm{G}^{\prime \prime}\right)$. Loss tangent values at $70^{\circ} \mathrm{C}$ decreased significantly $(P \leq 0.05)$ with increasing concentration of CCP in the cheese samples (Table 2; Figure 6). The $G^{\prime}$ values at $20^{\circ} \mathrm{C}$ tended to decrease with increasing concentration of CCP, but the differences were not significant $(P>$ 0.05 ). Storage modulus at $70^{\circ} \mathrm{C}$ was highly positively correlated with CCP concentration $(\mathrm{r}=0.90, P<$ 0.0001 ), and $\mathrm{G}^{\prime}$ at $20^{\circ} \mathrm{C}$ was negatively correlated with $\mathrm{CCP}$ concentration. The $\mathrm{G}^{\prime}$ value of each of the cheese samples increased slightly between 70 and $90^{\circ} \mathrm{C}$, the effect being more pronounced with decreasing concentration of CCP. A high $\mathrm{LT}_{\max }$ value indicates a short lifetime of protein-protein bonds (Renkema, 2002) and, therefore, a higher propensity for bond breakage and structural rearrangements in the cheese matrix with an increase in thermal energy (Van Vliet, 1999). A higher $\mathrm{LT}_{\max }$ value indicates a greater propensity of cheese to melt and flow when heated. Loss tangent values remained low ( $~ 0.2$ to 0.4$)$ in the temperature range from 10 to $50^{\circ} \mathrm{C}$ (Figure 5c). The values for $\mathrm{LT}_{\max }$ decreased significantly $(P \leq 0.05)$ with increasing concentration of CCP (Table 2), and varying CCP concentrations had no significant $(P>0.05)$ effect on the temperature at which $\mathrm{LT}_{\max }$ occurred (Table 2). The $\mathrm{LT}_{\max }$ was negatively correlated with CCP concentration $(\mathrm{r}=-0.98, P$ $<0.0001$ ). In agreement with these results, Lucey et al. (2005) reported $\mathrm{LT}_{\max }$ to be highly correlated $(\mathrm{r}=-0.92$, $P<0.0001$ ) with the insoluble Ca (i.e., CCP) content of Cheddar cheese during ripening. The temperature at $\mathrm{LT}_{\max }$ was more highly correlated with the extent of primary proteolysis than the level of insoluble Ca. Those researchers also observed the greatest increase in $\mathrm{LT}_{\max }$ between 3 and $30 \mathrm{~d}$ of ripening, which coincides with the rapid conversion of calcium from insoluble to soluble forms.

Fourier transform mechanical spectroscopy (also referred to as multiwave spectroscopy) is a relatively new rheological technique based on dynamic low amplitude oscillatory rheometry. Instead of applying a sinusoidal wave of a single frequency to the cheese sample (as in dynamic low amplitude oscillatory rheometry), FTMS

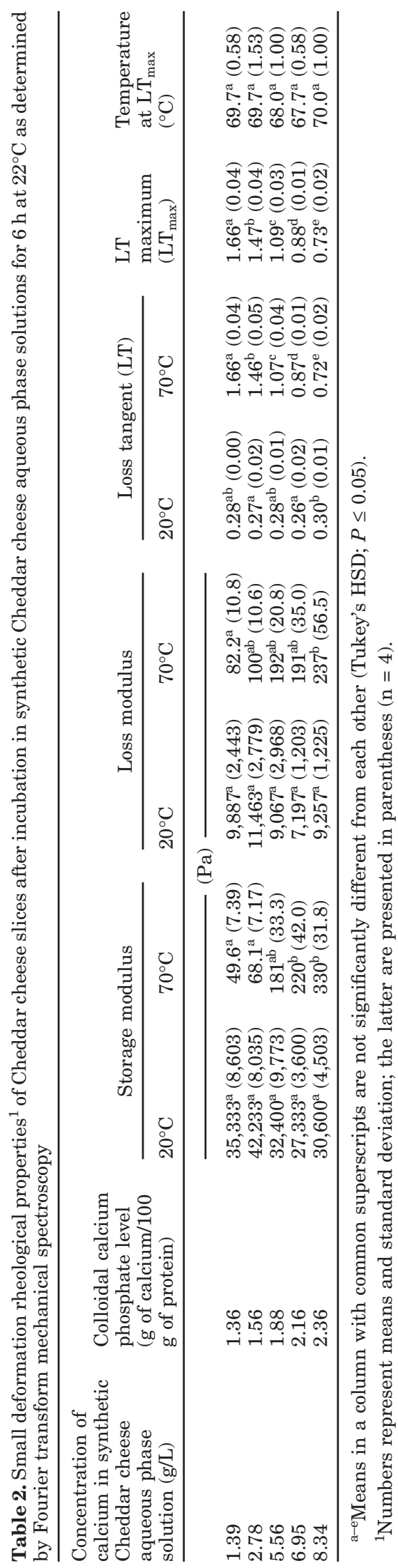

Journal of Dairy Science Vol. 89 No. 3, 2006 


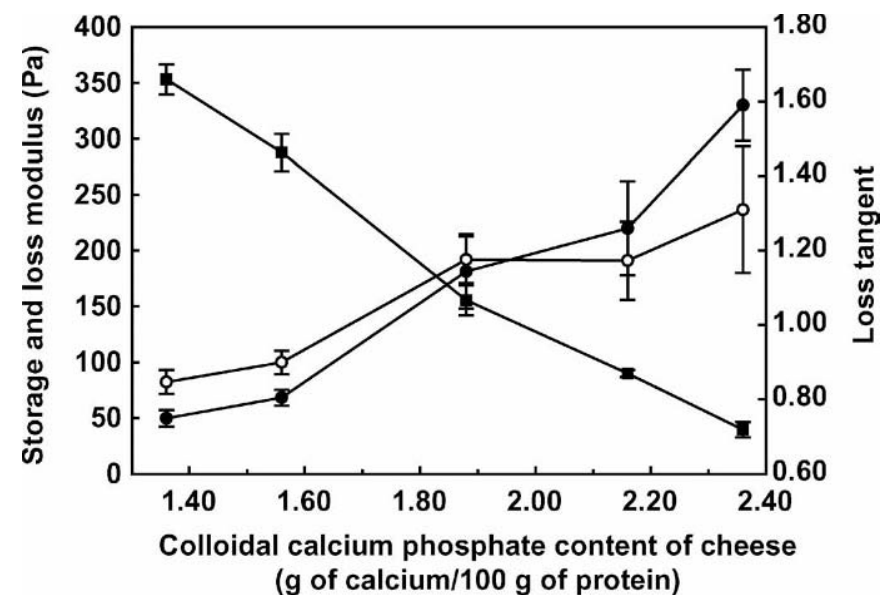

Figure 6. Storage modulus $(\bullet)$, loss modulus $(\bigcirc)$ and loss tangent (匹) as a function of colloidal calcium phosphate concentration of Cheddar cheese slices incubated in synthetic Cheddar cheese aqueous phase solutions for $6 \mathrm{~h}$ at $22^{\circ} \mathrm{C}$, measured at $70^{\circ} \mathrm{C}$ at a frequency of $0.4 \mathrm{~Hz}$. Error bars indicate $\pm 1 \mathrm{SD}(\mathrm{n}=4)$.

applies a complex sinusoidal wave that is a combination of several sine waves of differing frequencies; each of the individual frequencies of the complex waveform are harmonics of a base frequency (Nelson and Dealy, 1998). Thus, using FTMS, various rheological parameters can be quantified for each of the component frequencies simultaneously during a single experiment. The FTMS was originally developed for studying polymer gelation (Holly et al., 1988) and only recently has been applied to studying the rheological properties of cheese (Udayarajan et al., 2005). The frequency dependence of the mechanical properties of the cheese matrix increased with increasing measuring temperature from 20 to $70^{\circ} \mathrm{C}$ (Figure 7). The slope or exponent $(n)$ of a linear regression line from the plot of $\log \mathrm{G}^{\prime}$ against log of frequency provides information about the strength of a gel network (Lopes da Silva et al., 1996; Gunasekaran and Mehmet, 2000). The nearer the value of $n$ is to zero, the more closely the structure resembles that of a covalently linked chemical gel (i.e., a strong gel, the $\mathrm{G}^{\prime}$ of which is frequency independent). At $20^{\circ} \mathrm{C}$, the exponent values from log $G^{\prime}$ vs. log frequency plots for the 5 cheese samples were low, ranging from 0.18 to 0.20 , and there was no clear trend in exponent values with changing concentration of CCP (Figure 7). When measured at $70^{\circ} \mathrm{C}$, the exponent values were $0.39,0.43$, $0.51,0.64$, and 0.70 for cheeses with CCP concentrations of $2.36,2.16,1.88,1.56$, or $1.36 \mathrm{~g}$ of calcium/100 $\mathrm{g}$ of protein, respectively. There was a significant negative correlation between the exponent values measured at $70^{\circ} \mathrm{C}$ and concentration of $\mathrm{CCP}(\mathrm{r}=-0.97, P<0.0001)$. It is known that the frequency dependence of the cheese matrix increases with increasing measuring tempera-

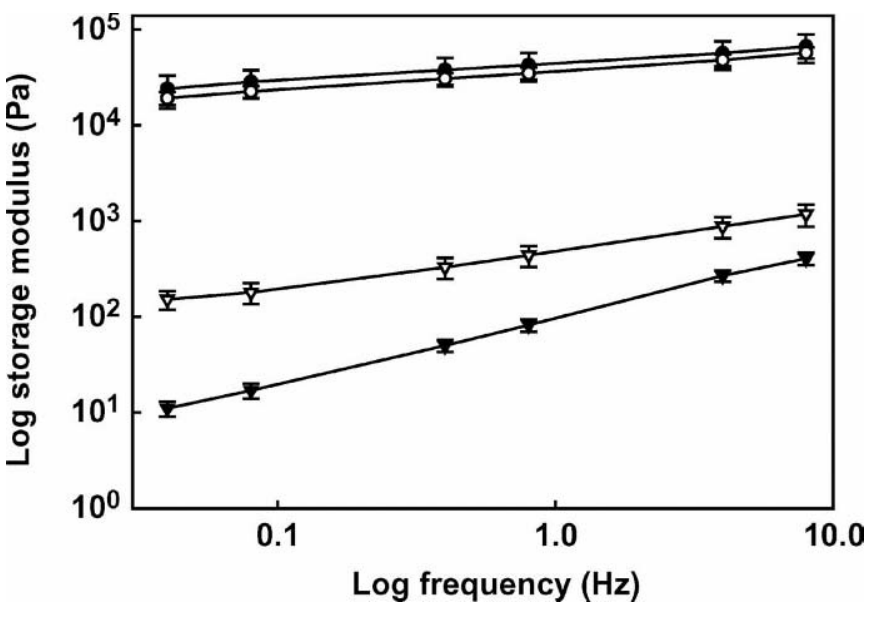

Figure 7. Storage modulus at $20^{\circ} \mathrm{C}(\bullet, \bigcirc)$ and at $70^{\circ} \mathrm{C}(\boldsymbol{\nabla}, \nabla)$ as a function of frequency in the range from 0.04 to $8.00 \mathrm{~Hz}$ for Cheddar cheese slices incubated in synthetic Cheddar cheese aqueous phase solutions containing 1.39 (closed symbols) or 8.34 (open symbols) g of calcium/L for $6 \mathrm{~h}$ at $22^{\circ} \mathrm{C}$. Error bars indicate $\pm 1 \mathrm{SD}(\mathrm{n}=4)$.

ture (Udayarajan et al., 2005); however, it appears that solubilization of CCP influences the frequency dependence of the mechanical properties of the cheese matrix only at high temperatures. The LT value at $70^{\circ} \mathrm{C}$ was also shown to be frequency dependent (Figure 8). Loss tangent values either remained relatively constant or decreased with increasing frequency, and the cheese samples with the lowest concentration of CCP exhibited the greatest frequency dependence. At any particular frequency, the LT values decreased as CCP concentration increased, illustrating that increasing $\mathrm{CCP}$ concen-

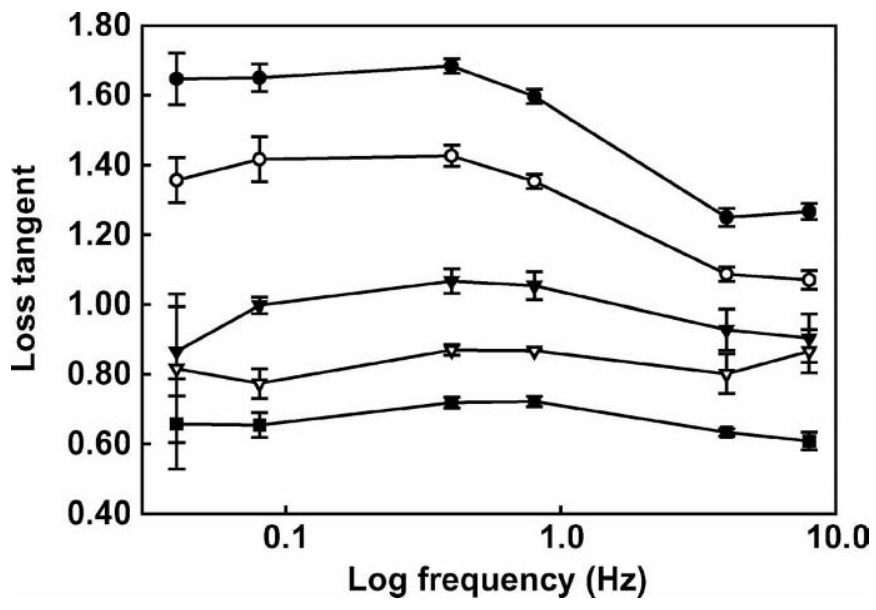

Figure 8. Loss tangent at $70^{\circ} \mathrm{C}$ as a function of frequency in the range from 0.04 to $8.00 \mathrm{~Hz}$ for Cheddar cheese slices incubated in synthetic Cheddar cheese aqueous phase solutions containing 1.39 $(\circlearrowleft), 2.78(\bigcirc), 5.56(\nabla), 6.95(\nabla)$, or $8.34(\mathbf{\square}) \mathrm{g}$ of calcium/L for $6 \mathrm{~h}$ at $22^{\circ} \mathrm{C}$. Error bars indicate $\pm 1 \mathrm{SD}(\mathrm{n}=4)$. 
tration reduces the susceptibility of the protein matrix of the cheese to undergo structural rearrangement, thus retarding melt and flow. Cheese samples incubated in SCCAP solutions with 6.95 and $8.34 \mathrm{~g}$ of calcium/L had LT values $<1.0$ (i.e., more solid), and cheese samples incubated in SCCAP solutions with 1.39, 2.78, and $5.56 \mathrm{~g}$ of calcium/L had LT values $>1.0$ (i.e., more liquid) for nearly all frequencies.

Colloidal Ca phosphate is one of the principal agents involved in maintaining the structure of native casein micelles via bridging or linking individual casein molecules (Horne, 1998). Hydrophobic interactions, another principal structural agent in casein micelles, increase in strength with increasing temperature and reach a maximum at approximately $70^{\circ} \mathrm{C}$ (Bryant and McClements, 1998; Lucey et al., 2003). In this context, it is possible that at low temperatures $\left(10\right.$ to $\left.20^{\circ} \mathrm{C}\right)$, solubilization of CCP combined with the relatively low strength of hydrophobic interactions, causes swelling of casein particles within the para-casein matrix of the cheese. This swelling effect would result in increased contact area between casein particles, which we believe to be responsible for the increase in $\mathrm{G}^{\prime}$ at $20^{\circ} \mathrm{C}$ with decreasing CCP concentration. Evidence of this swelling phenomenon may be drawn from the increase in hydration of the cheese samples with decreasing concentration of CCP (Table 1); the hydration values for cheese samples with CCP concentrations of 1.36 and $2.36 \mathrm{~g}$ of calcium/ $100 \mathrm{~g}$ of protein were 2.39 and $2.25 \mathrm{~g}$ of water/100 $\mathrm{g}$ of protein, respectively (Monib, 1962; Geurts et al., 1972; Sood et al., 1979).

The maximum in the strength of hydrophobic interactions at approximately $70^{\circ} \mathrm{C}$ induces strong associations within casein particles, reducing contact area, and consequently, the strength of interactions between casein particles, resulting in the minimum observed in $\mathrm{G}^{\prime}$ at $\sim 70$ to $75^{\circ} \mathrm{C}$ for each of the 5 cheese samples (Figure $5 a)$. The increase in $\mathrm{G}^{\prime}$ at $70^{\circ} \mathrm{C}$ with increasing concentration of CCP in the cheese samples is, presumably, the result of increased CCP bridging between casein molecules or particles, conferring more structural rigidity to the cheese matrix.

Regardless of concentration of CCP, each of the 5 cheese samples exhibited an increase in $\mathrm{G}^{\prime}$ with increasing temperature between 70 and $90^{\circ} \mathrm{C}$, which was confirmed by the decrease in LT values of each of the cheese samples after reaching a maximum at $\sim 70^{\circ} \mathrm{C}$. It has been postulated that the increase in $\mathrm{G}^{\prime}$ on heating in this range of temperature may be due to the formation of some structure by the interaction of newly formed (heat-induced) CCP and casein particles (Udayarajan et al., 2005). It is not clear whether this newly formed CCP is of the same form as that present in native casein micelles. Visual assessment of Figure 5a shows that the extent of increase in $\mathrm{G}^{\prime}$ between 70 and $90^{\circ} \mathrm{C}$ decreased as the concentration of CCP in the cheese samples increased. The calcium that may form this heatinduced CCP originates in the serum phase of the cheese, and as explained earlier, the concentration of calcium in the serum phase of Cheddar cheese increases with increasing ripening time because of the solubilization of CCP (Hassan et al., 2004; Lucey et al., 2005; O'Mahony et al., 2005). The data of Lucey et al. (2005) showed a flattening of $\mathrm{G}^{\prime}$ vs. temperature profiles in the high-temperature region with increasing ripening time of Cheddar cheese. Those researchers showed a distinct decrease in $\mathrm{G}^{\prime}$ on heating 3-d-old Cheddar cheese from 70 to $80^{\circ} \mathrm{C}$; however, there was an increase in $\mathrm{G}^{\prime}$ on heating the same cheese from 70 and $90^{\circ} \mathrm{C}$ at 9 mo of ripening. The concentration of soluble calcium was 28.0 and $42.5 \%$ (expressed as a percentage of total calcium in cheese) at $3 \mathrm{~d}$ and $9 \mathrm{mo}$, respectively. Thus, one may expect an inverse relationship between the concentration of CCP and the potential for formation of heat-induced CCP in Cheddar cheese.

Large Deformation Rheological Properties. The large deformation rheological properties of Cheddar cheese samples incubated in SCCAP solutions containing 1.39 or $6.95 \mathrm{~g}$ of calcium/L are shown in Table 3. Increasing the concentration of $\mathrm{Ca}$ in the SCCAP solution (and thus the CCP content of the cheeses) significantly $(P \leq 0.05)$ increased the force at 20 and $75 \%$ compression, fracture force, and adhesive force. The concentration of $\mathrm{Ca}$ in the SCCAP solution had no significant effect on force at 5\% compression, fracture strain, or adhesiveness. Differences between the 2 cheese samples, in terms of force required to compress the samples, decreased as the percentage of compression decreased from 75 to $5 \%$. The results of large deformation (compression) tests supported the results of small deformation tests (FTMS); i.e., at low strain $(\leq 5 \%)$ and low temperature $\left(\leq 20^{\circ} \mathrm{C}\right)$, there were no significant $(P>0.05)$ differences in the rheological properties of cheeses incubated in SCCAP solutions with calcium concentrations in the range from 1.39 to $6.95 \mathrm{~g} / \mathrm{L}$.

\section{CONCLUSIONS}

The model system developed in this study was extremely effective for postmanufacture alteration of the CCP concentration of Cheddar cheese, independent of proteolysis. Changes in CCP concentration impacted the large strain deformation (i.e., fracture) properties of Cheddar cheese. Colloidal Ca phosphate concentration had a strong influence on the small deformation rheological properties of Cheddar cheese during heating; however, these effects were confined largely to the 50 to $90^{\circ} \mathrm{C}$ temperature range. The potential for modifica- 
Table 3. Rheological properties ${ }^{1}$ of Cheddar cheese slices after incubation in synthetic Cheddar cheese aqueous phase solutions containing 1.39 or $6.95 \mathrm{~g}$ of calcium/L for $6 \mathrm{~h}$ at $22^{\circ} \mathrm{C}$ determined by compression testing

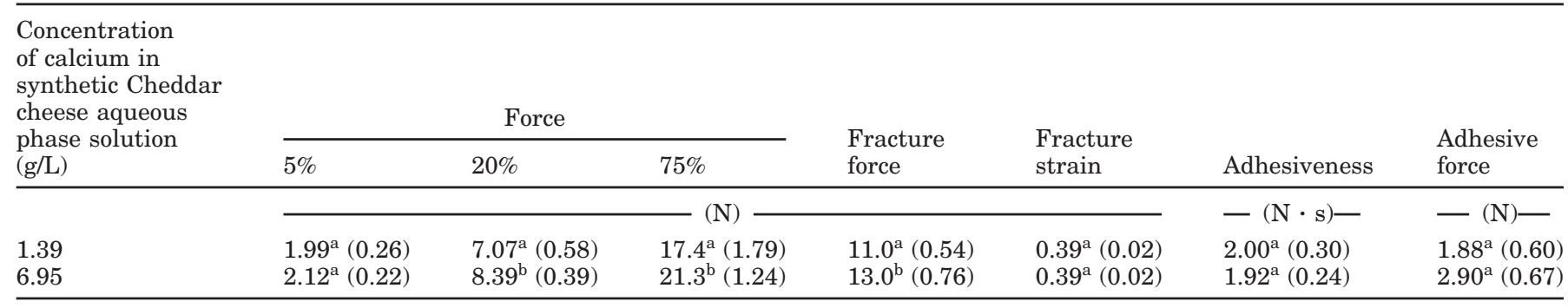

${ }^{\mathrm{a}, \mathrm{b}}$ Means in a column with common superscripts are not significantly different from each other (Tukey's HSD; $P \leq 0.05$ ).

${ }^{1}$ Numbers represent means and standard deviation; the latter are presented in parenthesis $(\mathrm{n}=6)$.

tions to protein-protein interactions such as bond breakage and structural rearrangement (prerequisites for melt and flow of cheese), decreased with increasing concentration of CCP in this temperature range.

The model system developed in this study may also be used for investigations into the effects of enzymes or chemical compounds on cheese texture. These materials could be added to SCCAP prior to incubation. This approach avoids the need for expensive cheesemaking operations and removes complications associated with using different cheese samples (e.g., differences in composition and age). This research demonstrated that CCP has a key role in determining cheese meltability, which is an important functional property. The composition of serum phase plays a critical role in modulating the level of CCP in cheese. When cheese was incubated in SCCAP that had low calcium content, the calcium was lost from the cheese serum phase to attain some type of equilibrium. During the early stages of cheese ripening, there is a steady loss of calcium from CCP (Hassan et al., 2004), probably because the concentration of calcium in the cheese serum phase is lower than the stable equilibrium level with $\mathrm{CCP}$ for those cheese conditions.

\section{ACKNOWLEDGMENTS}

J. A. O'Mahony gratefully acknowledges the financial support of a travel bursary from the National University of Ireland, which facilitated this research at the University of Wisconsin-Madison. The authors thank Malcolm Broome for suggestions on the cheese aqueous phase model system. The financial support of Dairy Management Inc. (Rosemont, IL) is greatly appreciated.

\section{REFERENCES}

Bourne, M. C. 1978. Texture profile analysis. Food Technol. 32:6266,72 .

Broome, M. C., and G. K. Y. Limsowtin. 2002. Development of a cheese aqueous phase model. Aust. J. Dairy Technol. 57:118.
Bryant, C. M., and D. J. McClements. 1998. Molecular basis of protein functionality with special consideration of cold-set gels derived from heat-denatured whey. Trends Food Sci. Technol. 9:143-151.

Creamer, L. K., R. C. Lawrence, and J. Gilles. 1985. Effect of acidification of cheese milk on the resultant Cheddar cheese. N. Z. J. Dairy Sci. Technol. 20:185-203.

Creamer, L. K., and N. F. Olson. 1982. Rheological evaluation of maturing Cheddar cheese. J. Food Sci. 47:631-646.

Fox, P. F., T. M. Cogan, T. P. Guinee, and P. L. H. McSweeney. 2000. Fundamentals of Cheese Science. Aspen Publishers Inc., Gaithersburg, MD.

Fox, P. F., and P. L. H. McSweeney. 1998. Dairy Chemistry and Biochemistry. Chapman and Hall, London, UK.

Geurts, T. J., P. Walstra, and H. Mulder. 1972. Brine composition and the prevention of the defect "soft rind" in cheese. Neth. Milk Dairy J. 26:168-179.

Gilles, J., and R. C. Lawrence. 1973. The assessment of Cheddar cheese quality by compositional analysis. N. Z. J. Dairy Sci. Technol. 8:148-151.

Guinee, T. P. 2003. Role of protein in cheese and cheese products. Pages 1083-1174 in Advanced Dairy Chemistry. Vol. 1, Proteins, 3rd ed. P. F. Fox and P. L. H. McSweeney, ed. Kluwer Academic/ Plenum Publishers, New York, NY.

Guinee, T. P., M. A. E. Auty, and C. Mullins. 1999. Observations on the microstructure and heat-induced changes in the viscoelasticity of commercial cheeses. Aust. J. Dairy Technol. 54:84-89.

Guinee, T. P., E. P. Feeney, M. A. E. Auty, and P. F. Fox. 2002. Effect of $\mathrm{pH}$ and calcium concentration on some textural and functional properties of Mozzarella cheese. J. Dairy Sci. 85:1655-1669.

Gunasekaran, S., and A. K. Mehmet. 2000. Dynamic oscillatory shear testing of foods-Selected applications. Trends Food Sci. Technol. 11:115-127.

Guo, M. R., and P. S. Kindstedt. 1995. Age-related changes in the water phase of Mozzarella cheese. J. Dairy Res. 78:2099-2107.

Hassan, A., M. E. Johnson, and J. A. Lucey. 2004. Changes in the proportions of soluble and insoluble calcium during the ripening of Cheddar cheese. J. Dairy Sci. 87:854-862.

Holly, E. E., S. K. Venkataraman, F. Chambon, and H. H. Winter. 1988. Fourier transform mechanical spectroscopy of viscoelastic materials with transient nature. J. Non-Newtonian Fluid Mech. $27: 17-26$.

Horne, D. S. 1998. Casein interactions: Casting light on the black boxes, the structure in dairy products. Int. Dairy J. 8:171-177.

IDF. 1964. Determination of the protein content of processed cheese products. 25:1964. International Dairy Federation, Brussels, Belgium.

IDF. 1982. Cheese and processed cheese. Determination of the total solids content. 4A:1982. International Dairy Federation, Brussels, Belgium.

IDF. 2003. Determination of calcium, sodium, potassium and magnesium contents-Atomic absorption spectroscopic method. 119:2003. International Dairy Federation, Brussels, Belgium. 
Joshi, N. S., K. Muthukumarappan, and R. I. Dave. 2002. Role of soluble and colloidal calcium contents on functionality of salted and unsalted part-skim Mozzarella cheese. Aust. J. Dairy Technol. 57:203-210.

Joshi, N. S., K. Muthukumarappan, and R. I. Dave. 2003. Understanding the role of calcium in functionality of part-skim Mozzarella cheese. J. Dairy Sci. 86:1918-1926.

Kindstedt, P. S. 2004. Mozzarella cheese: 40 years of scientific advancements. Int. J. Dairy Technol. 57:85-90.

Kindstedt, P. S., A. Zielinski, M. Almena-Aliste, and C. Ge. 2001. A post-manufacture method to evaluate the effect of $\mathrm{pH}$ on Mozzarella cheese characteristics. Aust. J. Dairy Technol. 56:202-207.

Lawrence, R. C., L. K. Creamer, and J. Gilles. 1987. Texture development during cheese ripening. J. Dairy Sci. 70:1748-1760.

Lawrence, R. C., J. Gilles, and L. K. Creamer. 1983. The relationship between cheese texture and flavour. N. Z. J. Dairy Sci. Technol. 18:175-190.

Lee, M.-R., M. E. Johnson, and J. A. Lucey. 2005. Impact of modifications in acid development on the insoluble calcium content and rheological properties of Cheddar cheese. J. Dairy Sci. 88:3798-3809.

Lopes da Silva, J. A., M. P. Goncalves, J. L. Doublier, and M. A. V. Axelos. 1996. Effect of galactomannans on the viscoelastic behaviour of pectin/calcium networks. Poly. Gels Networks 4:65-83.

Lucey, J. A., and P. F. Fox. 1993. Importance of calcium and phosphate in cheese manufacture: A review. J. Dairy Sci. 76:1714-1724.

Lucey, J. A., B. Hauth, C. Gorry, and P. F. Fox. 1993. The acid-base buffering properties of milk. Milchwissenschaft 48:268-272.

Lucey, J. A., M. E. Johnson, and D. S. Horne. 2003. Perspectives on the basis of the rheology and texture properties of cheese. J. Dairy Sci. 86:2725-2743.

Lucey, J. A., R. Mishra, A. Hassan, and M. E. Johnson. 2005. Rheological and calcium equilibrium changes during ripening of Cheddar cheese. Int. Dairy J. 15:645-653.

Metzger, L. E., D. M. Barbano, M. A. Rudan, and P. S. Kindstedt. 2000. Effect of milk preacidification on low fat Mozzarela cheese: 1. Composition and yield. J. Dairy Sci. 83:646-658.

Monib, A. M. M. F. 1962. The calcium-paracaseinate-phosphate complex under conditions similar to those in cheese. Meded. Landbouwhogesch Wageningen 62:1-76.
Nelson, B. I., and J. M. Dealy. 1998. Dynamic mechanical analysis using complex waveforms. Pages 138-151 in Rheological Measurement. 2nd ed. A. A. Collyer and D. W. Clegg, ed. Chapman and Hall, London, UK.

Nolan, E. J., V. H. Holsinger, and J. J. Sheih. 1989. Dynamic rheological properties of natural and imitation Mozzarella cheeses. J. Texture Stud. 20:179-183.

O’Mahony, J. A., J. A. Lucey, and P. L. H. McSweeney. 2005. Chymosin-mediated proteolysis, calcium solubilization and texture development during the ripening of Cheddar cheese. J. Dairy Sci. 88:3101-3114.

Pastorino, A. J., N. P. Ricks, C. L. Hansen, and D. J. McMahon 2003. Effect of calcium and water injection on structure-function relationships of cheese. J. Dairy Sci. 86:105-113.

Renkema, J. M. S. 2002. Formation, structure and rheological properties of soy protein gels. M.Sc. Thesis, Wageningen Agricultural Univ., The Netherlands.

SAS Institute. 1999. SAS User's Guide. Release 8.0. SAS Inst., Inc., Cary, NC.

Sheehan, J. J., and T. P. Guinee. 2004. Effect of $\mathrm{pH}$ and calcium level on the biochemical, textural and functional properties of reducedfat Mozzarella cheese. Int. Dairy J. 14:161-172.

Sood, S. M., D. K. Gaind, and R. K. Dewan. 1979. Correlation between micelle solvation and calcium content. N. Z. J. Dairy Sci. Technol. $14: 32-34$.

Tunick, M. H., E. J. Nolan, J. J. Shieh, M. P. Thompson, B. E. Maleeff, and V. H. Holsinger. 1990. Cheddar and Cheshire cheese rheology. J. Dairy Sci. 73:1671-1675.

Udayarajan, C. T., J. A. Lucey, and D. S. Horne. 2005. Use of Fourier transform mechanical spectroscopy to study the melting behavior of cheese. J. Texture Stud. 36:489-515.

Van Slyke, D. D. 1922. On the measurement of buffer value and on the relationship of buffer value to the dissociation constant of the buffer and the concentration and reaction of the buffer solution. J. Biol. Chem. 52:525-571.

Van Vliet, T. 1999. Factors determining small-deformation behaviour of gels. Pages 307-317 in Food Emulsions and Foams; Interfaces, Interactions and Stability. E. Dickinson and J. M. Rodriguez Patino, ed. R. Soc. Chem., Cambridge, UK.

Venugopal, V., and K. Muthukumarappan. 2003. Rheological properties of Cheddar cheese during heating and cooling. Int. J. Food Prop. 6:99-114. 